\title{
Associação de Angiogênese com Características Anatomopatológicas no Carcinoma do Colo Uterino
}

Autor: Sabas Carlos Vieira

Orientador: Prof. Dr. Luiz Carlos Zeferino

Tese apresentada ao Curso de Mestrado em Ciências Médicas da Universidade Estadual de Campinas, em 14.02.2003

O conhecimento sobre a angiogênese do carcinoma do colo uterino concentra-se no estudo de Vascular Endothelial Growth Factor, Fator VIII ou de von Willebrand, Ulex europaeus lectin e CD31. Novos marcadores de células endoteliais, como os anticorpos anti-CD34 e BNH9, são pouco conhecidos em relação ao carcinoma do colo uterino.

Portano, o objetivo deste estudo foi analisar a associação da atividade angiogênica com as características anátomo-patológicas no carcinoma do colo uterino, utilizando os anticorpos monoclonais anti-CD34, BNH9 e anti-CD31. Para tal foi realizado um estudo transversal descritivo, que incluiu 62 pacientes com carcinoma invasivo do colo uterino nos estádios Ib1, Ib2 e IIa da FIGO, que submeteram-se a histerectomia radical com linfadenectomia pélvica no periodo de janeiro de 2000 a fevereiro de 2002. Para o estudo imunoistoquímico da angiogênese foi utilizado anticorpo primário monoclonal específico para o antígeno CD34 (Anti-Human Haematopoietic Progenitor Cell, CD34 Class II, Clone QBEnd 10, Code M 7165, Dako Corporation, Dakopatts, Carpintereria, USA) na diluição de 1:25 com soroalbumina bovina (BSA), anticorpo primário monoclonal específico para o antígeno CD31 (Anti-Human Endothelial Cell, Clone JC/70A, DAKO Corporation Dakopatts, Carpinteria, USA) na diluição 1:30 e o anticorpo monoclonal BNH9, gentilmente cedido pelo Prof. George Delsol, Toulouse-
França. A mensuração da angiogênese foi feita através da contagem do total de microvasos em 10 campos e da densidade de microvasos que correspondeu à média de microvasos por campo.

Observou-se que todos os casos apresentaram resultados positivos para o anti-CD34, enquanto quatro e 17 casos foram negativos, respectivamente para o antiBNH9 e anti-CD31. A densidade de microvasos foi maior quando utilizou-se o anticorpo monoclonal antiCD34 e BNH9 do que com anti-CD31. Maior densidade de microvasos determinada pelo anticorpo antiCD34 associou-se com carcinoma do colo uterino do tipo histológico escamoso, enquanto que com o anti CD-31 associou-se com o carcinoma indiferenciado. Maior densidade de microvasos determinada pelo anticorpo BNH9 associou-se com linfonodos comprometidos no carcinoma escamoso do colo uterino. Quando utilizaram os anticorpos anti-CD34 e BNH9 observou-se tendência de associar-se com invasão linfática para o carcinoma do colo uterino.

A atividade angiogênica é mais alta nos carcinomas escamosos, nos carcinomas indiferenciados e quando houver linfonodos comprometidos no carcinoma escamoso.

Palavras chave: Colo: câncer. Angiogênese. Imunoistoquímica.

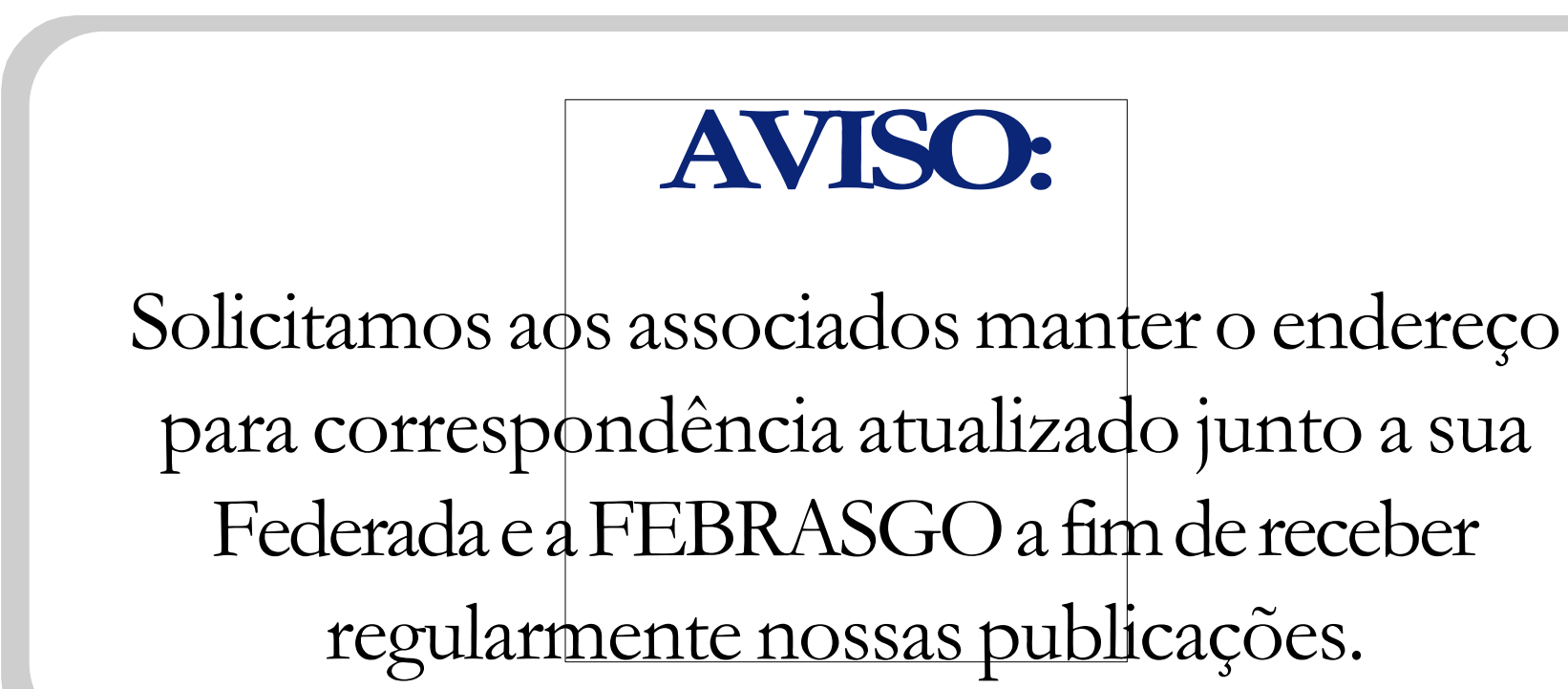

